\title{
Clinical significance of atypical squamous cells of undetermined significance after treatment for cervical intraepithelial grade 3 neoplasia: A retrospective single-center cohort study
}

\author{
TOSHIMICHI ONUMA ${ }^{1,2}$, KIMIHISA TAJIMA ${ }^{2}$, KUMIKO SATO ${ }^{2}$, KATSUSHIGE HATTORI ${ }^{2}$, \\ SHIN FUKUDA ${ }^{2}$, TAKAHIRO TSUJI ${ }^{2}$ and YOSHIO YOSHIDA ${ }^{1}$ \\ ${ }^{1}$ Department of Obstetrics and Gynecology, Faculty of Medical Sciences, University of Fukui, Fukui 910-1193; \\ ${ }^{2}$ Department of Obstetrics and Gynecology, Fukui Red Cross Hospital, Fukui 918-8501, Japan
}

Received May 4, 2017; Accepted September 28, 2017

DOI: $10.3892 / \mathrm{mco} .2017 .1443$

\begin{abstract}
The aim of the present study was to evaluate the clinical significance of atypical squamous cells of undetermined significance (ASC-US) following cervical conization for cervical intraepithelial neoplasia (CIN) grade 3. This study was a retrospective cohort analysis. The medical records of women treated with conization for CIN 2-3 were reviewed and 142 patients with CIN 3 who had been diagnosed using the conization specimens were selected. The mean follow-up period after conization was 41.8 months. Cytological abnormalities after conization were observed in $19.0 \%$ of the patients and consisted of ASC-US (13.4\%) and worse than low-grade squamous intraepithelial lesion (LSIL; 5.6\%). Recurrence was defined as a diagnosis worse than CIN 2, and the recurrence rate was $29.6 \%$ among patients with abnormal cytology. The recurrence rate was $15.7 \%$ in the ASC-US group and $71.4 \%$ in the worse than LSIL group. There was no significant difference in the time of initial identification of abnormal cytology after treatment between the worse than LSIL and the ASC-US groups $(\mathrm{P}=0.054)$. However, the ASC-US group had a significantly better cumulative recurrence-free rate compared with the worse than LSIL group $(\mathrm{P}<0.05)$. Women with ASC-US following treatment for CIN appear to be at a relatively high risk. Regarding the risk stratification of women following treatment for CIN, if surveillance cytology shows ASC-US, immediate colposcopy is recommended, along with long-term follow-up.
\end{abstract}

Correspondence to: Dr Yoshio Yoshida, Department of Obstetrics and Gynecology, Faculty of Medical Sciences, University of Fukui, 23-3 Matsuoka-Shimoaizuki, Eiheiji-cho, Fukui 910-1193, Japan E-mail: yyoshida@u-fukui.ac.jp

Key words: cervical intraepithelial neoplasia grade 3, conization, follow-up cytology, atypical squamous cells of undetermined significance, recurrence

\section{Introduction}

Cervical conization is the recommended treatment for cervical intraepithelial neoplasia (CIN) grade 3 (1). Based on the available evidence, there is no optimal surveillance strategy following treatment for CIN (2). For early detection of recurrence, long-term follow-up after cervical conization has been recommend by the American College of Obstetricians and Gynecologists (ACOG) guidelines (3).

In Japan, the national screening guidelines for women under the National Health Insurance system state that cervical conventional cytology using Pap smears is a standard screening test for cervical cancer. Human papillomavirus (HPV) DNA testing has not been recommended for population-based screening due to the scarcity of scientific evidence. However, when conventional cervical cytology shows atypical squamous cells of undetermined significance (ASC-US), repeat cervical cytology after 6 and 12 months, immediate colposcopy, or HPV DNA triage have been recommended by the National Cancer Comprehensive Network (NCCN) guidelines (4).

Although ASC-US comprise a wide variety of cervical cells, including benign and malignant cells, the presence of ASC-US has been considered as a low-risk abnormal cervical cytological characteristic (5). However, a substantial proportion of cases displaying ASC-US have underlying high-grade CIN (2 or 3) and, thus, are at an increased risk of developing cervical cancer (6). Based on these facts, it appears reasonable to consider women with ASC-US following treatment for CIN to be at a relatively increased risk of developing cervical cancer compared with women with ASC-US after no treatment. As regards risk stratification for women following treatment for CIN, an appropriate triage method used to identify women with ASC-US who have or will develop a cervical cancer precursor is crucial. The clinical significance of ASC-US following cervical conization for CIN, particularly for CIN 3 , which has a high risk of recurrence, has not been fully elucidated. The aims of the present study were to evaluate the clinical significance of ASC-US following cervical conization for CIN 3 and to suggest an appropriate triage method. 


\section{Patients and methods}

Study population. This was a retrospective cohort study. In order to identify cases with cytological abnormalities following conization, the medical records of patients who received conization as a conservative treatment for CIN 2-3 were reviewed. A total of 142 cases with CIN 3 that had been diagnosed using the conization specimens between February 2005 and May 2015 in our hospital were ultimately considered as eligible for review.

Conization procedure. Conization was performed using yttrium-aluminum-garnet (YAG) laser or ultrasonic scalpel under spinal anesthesia. Prior to resection, the squamous columnar junction (SCJ) was examined using the Schiller test.

The YAG laser procedure was performed as follows: The cervix was sutured, pulling the line to the outside of the SCJ. Towing the line, cervical excision was performed with the YAG laser at $12 \mathrm{~W}$. The resection stump was coagulated with the laser.

The ultrasonic scalpel procedure was as follows: The cervix was sutured, pulling the line to the outside of the SCJ. Cervical excision was performed using output level 3 of the Harmonic Scalpel. The use of equipment was determined by the attending physician.

Surveillance after treatment for CIN 3. A conventional Pap smear was performed after conization at a time left to the discretion of each physician. The physicians conducted the follow-up based on the guidelines determined by the Office of Gynecology in Japan and the NCCN guidelines (4).

Identification of abnormal cytology and recurrence after treatment. Abnormal cytology was defined as worse than ASC-US. ASC-US was determined by one cytoscreener and one cytopathologist based on the Bethesda guidelines (7). Recurrence was defined as a diagnosis worse than CIN 2 in any pathological specimen at any timepoint during the follow-up period. The pathological specimens were independently reviewed by two gynecological pathologists.

HPV testing. Some ASC-US patients underwent high-risk HPV DNA testing (Hybrid Capture test using SurePath (BD Biosciences, Sparks, MD, USA) as the collection method). The high-risk HPV DNA test detects 13 different HPV types (16, 18, 31, 33, 35, 39, 45, 51, 52, 56, 58, 59, 68) (8). High-risk HPV DNA testing in patients with ASC-US was left to the discretion of the physicians.

Statistical analysis. Data were analyzed using the SPSS 21.0 software (IBM Corp., Armonk, NY, USA). Based on the postoperative cytology results, patients with abnormal cytology after conization were divided into an ASC-US group and a worse than low-grade squamous intraepithelial lesion (LSIL) group. The data are presented as means \pm standard deviation (SD) for quantitative variables and frequencies (\%) for qualitative variables. Student's t-test was used to compare means or medians, and the Chi-squared test or Fisher's exact test were used, as appropriate, to compare the frequency distributions of categorical variables. Pearson's $\chi^{2}$ test was used to analyze categorical variables. Kaplan-Meier survival curves with log-rank tests, with patient status at the time of the last follow-up visit, were used to compare the cumulative recurrence-free rates among the normal, ASC-US, and worse than LSIL groups. A P-value of $<0.05$ was considered to indicate statistically significant differences.

\section{Results}

Patient characteristics. The mean age of the 142 patients was 36.1 years. The mean age was not significantly different between the normal and the abnormal cytology groups. The mean follow-up period after conization was 41.8 months.

Cytological abnormalities after conization were observed in 27 patients (19\%), whereas the remaining 115 patients had normal cytological findings. There were no significant differences in age, surgical instrument, postoperative visit frequency, duration, or intervals between the abnormal and the normal cytology groups (Table I).

Identification of abnormal cytology after treatment. Of all the participants in this study, 19 (13.3\%) had ASC-US, and $8(5.6 \%)$ had a diagnosis worse than LSIL. There was no significant difference in the mean age between the two groups (35.3 vs. 35.9 years, respectively). The rate of cytological abnormalities did not differ significantly among the negative margin, the positive margin, and the non-assessable margin groups $\left(\chi^{2}=0.104\right)$. However, in the abnormal cytology group, there was a significant positive association between the rate of using YAG laser conization and the positive margin status of the excised specimen group $\left(\chi^{2}=0.036\right.$; Table II $)$.

ASC-US group. In this group, there were negative margins in 11 patients, positive margins in 7 patients, and a non-assessable margin in 1 patient. There were 3 different approaches to management based on the Japanese and NCCN guidelines. High-risk HPV tests were performed in 11 cases (including 7 negative-margin cases, 3 positive-margin cases and case with a non-assessable margin); the high-risk HPV test was positive in 6 cases (including 2 negative-margin cases using the ultrasonic scalpel, 1 negative-margin case using the YAG laser, 2 positive-margin cases using the YAG laser, and 1 non-assessable margin case using the YAG laser). Colposcopy with cervical biopsy was performed in 4 cases; 2 cases of CIN 1 and 2 cases of CIN 2 were detected (1 positive-margin case using the YAG laser and 1 negative-margin case using the ultrasonic scalpel). One patient underwent re-excision, and the result was negative for dysplasia. A total of 5 patients were negative for high-risk HPV (including 4 negative-margin patients and 1 positive-margin patient). Of those 5 patients, 4 were followed up by repeat cervical cytology, and all the cytological results were negative. In one case, hysterectomy was performed at the patient's request, and the result was negative for dysplasia.

The high-risk HPV test was not performed in 8 cases (including 4 negative-margin and 4 positive-margin cases). Of the 8 cases, 5 ( 3 negative-margin and 2 positive-margin) were followed up by repeat cervical cytology, and all the cytological results were negative. Immediate colposcopy with cervical biopsy was performed in 1 patient (with a positive margin), and no dysplasia was detected. Two patients (1 negative-margin and 
Table I. Patient characteristics $(n=142)$.

Cytological findings after treatment

\begin{tabular}{lcc}
\cline { 2 - 3 } Characteristics & Normal & Abnormal \\
\hline Number of patients & 115 & 27 \\
Mean age, years & 36.2 & 35.5 \\
Conization procedure, n (\%) & & \\
$\quad$ Ultrasonic scalpel & $38(33.0)$ & $12(44.4)$ \\
YAG laser & $77(67.0)$ & $15(55.6)$ \\
Margins status of the excised & & \\
specimens, $\mathrm{n}$ & & \\
$\quad$ Negative & 32 & 13 \\
Positive & 17 & 2 \\
$\quad$ Not assessable & & \\
Postoperative follow-up visits & $7.1(6)$ & $7.5(6)$ \\
Mean total number of visits & & \\
(median) & $42.0(33)$ & $41.1(31)$ \\
Mean duration, months (median) & 5.6 & 5.2 \\
Mean interval, months & &
\end{tabular}

YAG, yttrium-aluminum-garnet.

1 positive-margin) underwent immediate colposcopy followed by hysterectomy at their request; 1 of the patients had CIN 3, and the other patient had CIN 1 (Table III).

Worse than LSIL group. In this group, there were 2 negative-margin patients, 5 positive-margin patients, and 1 non-assessable margin patient. There were 4 cases of LSIL (3 positive-margin and 1 non-assessable margin), 3 cases of high-grade squamous intraepithelial lesion (HSIL) (2 negative-margin and 1 positive-margin), and 1 case of atypical squamous cells, which cannot exclude high-grade squamous intraepithelial lesion (ASC-H) (a positive-margin case) (Table IV).

Of the 8 patients, 7 underwent immediate colposcopy. Two patients with LSIL (both with non-assessable margin) had negative findings on colposcopy and were then followed up with repeat and cervical cytological examination, which have been normal thus far. Colposcopy with cervical biopsy was performed after 4 re-excisions. All the patients exhibited CIN 3 (including 1 HSIL with negative margins, 2 LSIL with positive margins, and $1 \mathrm{HSIL}$ with positive margins). In the single remaining case, hysterectomy was performed at the patient's request, with ASC-H including a positive margin, and CIN 3 was detected in this case. One patient was lost to follow-up for unknown reasons (Table IV).

Identification of recurrent disease. Based on colposcopy with cervical biopsy, re-excision, and hysterectomy after detecting abnormal cytology, CIN 2 and CIN 3 were diagnosed in 8 of the 142 cases. The recurrence rate of CIN 2 and CIN 3 was $5.6 \%$ of all cases and $29.6 \%(8 / 27)$ in the abnormal cytology cases. The recurrence rate was $15.7 \%(3 / 19)$ in the ASC-US group and $71.4 \%(5 / 7)$ in the worse than LSIL group. The cumulative recurrence-free rate was significantly better for the ASC-US group compared with that in the worse than LSIL group (log-rank test $\mathrm{P}<0.05$; Fig. 1). All cases of worse than LSIL that underwent histopathological examination were diagnosed with CIN 3.

Postoperative identification of abnormal cytology and recurrence time. There was no significant difference in the time to first identification of abnormal cytology after treatment between the worse than LSIL and the ASC-US groups (12.12 \pm 15.2 vs. $24.73 \pm 30.6$, respectively; $\mathrm{P}=0.054$; Student's t-test). There was no significant difference in the time to first identification of abnormal cytology after treatment by margin status of the excised specimens (positive, 16 \pm 23.5 ; negative, 28 \pm 3.24 ; non-assessable, $17.4 \pm 15.02$ months; $\mathrm{P}=0586$; Kruskal-Wallis test). However, there was a significant difference in the time to first identification of abnormal cytology after treatment between the recurrence and the no recurrence groups (32.37 \pm 40.18 vs. $16.21 \pm 19.19$, respectively; $\mathrm{P}=0.003$; Student's t-test).

\section{Discussion}

ASC-US was the most common abnormal cytological finding after treatment for CIN 3. Among all participants, $19 \%$ displayed cytological abnormalities after treatment in this study; the rate of ASC-US was $13.3 \%$, and that of worse than LSIL 5.6\%. The recurrence rate was $15.7 \%$ (3/19) in the ASC-US group and $71.4 \%(5 / 7)$ in the worse than LSIL group.

The Bethesda System (2001 revision) was adopted in 1988 (7). ASC-US accounts for $90 \%$ of ASC cases in American standard facilities, and ASC-H accounts for $10 \%$. With respect to the frequency of ASC, it has been suggested that good management requires that the ASC:SIL ratio be maintained at $<1.5$, and the frequency of ASC be maintained at $<5 \%$ of all cervical screenings (7). With respect to the accuracy of cancer screenings in our institute, the rate of negative cytology results in conventional cancer screenings $(95 \%)$ was similar to the rate of normal cytology results using conventional cytology (96\%) in the Canadian Cervical Cancer Screening Trial (9).

In the population-based screening phase, it has been reported that ASC-US were found in $<1 \%$ of the cases in a single population-based study (10). Solomon et al reported that $<4 \%$ of U.S. women were given an equivocal cervical cytological diagnosis (ASC-US) annually (11). Based on these facts, the results obtained in the present study revealed a rate of ASC-US that appears to be quite high (13.3\%) compared with these previous reports. ASC-US comprises a wide variety of cervical cells, including benign and malignant cells, and it appears reasonable to suggest that a proportion of women who receive treatment for CIN with ASC-US have postoperative inflammation resulting in altered cell morphology.

In addition, it has been reported that, on conventional cervical cytology alone, ASC-US accounts for $6.9 \%$ of CIN $2,2.6 \%$ of CIN 3 , and $0.18 \%$ of cervical cancer cases (12). In the present study, the recurrence rate was $15.7 \%$ (3/19) in the ASC-US group. CIN 2 and CIN 3 were the final pathological diagnoses in $2 / 19(10.5 \%)$ and $1 / 19(5.2 \%)$ patients, respectively. The 2 CIN 2 cases ( 1 with a positive margin using 
Table II. Association of abnormal cytology and conization procedure with margin status.

Margin status of the excised specimens, $\mathrm{n}$

\begin{tabular}{|c|c|c|c|c|c|c|}
\hline \multirow{2}{*}{$\begin{array}{l}\text { Cytology } \\
\text { after treatment }\end{array}$} & \multirow[b]{2}{*}{ Conization procedure } & \multicolumn{4}{|l|}{ 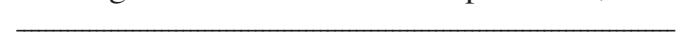 } & \multirow[b]{2}{*}{ P-value (Pearson's $\chi^{2}$ test) } \\
\hline & & Negative & Positive & Unclear & Total & \\
\hline \multirow[t]{3}{*}{ Normal } & YAG laser & 42 & 25 & 10 & 77 & 0.267 \\
\hline & Ultrasonic scalpel & 24 & 7 & 7 & 38 & \\
\hline & Total & 66 & 32 & 17 & 115 & \\
\hline \multirow[t]{3}{*}{ Abnormal } & YAG laser & 4 & 9 & 1 & 15 & 0.036 \\
\hline & Ultrasonic scalpel & 9 & 3 & 1 & 12 & \\
\hline & Total & 13 & 12 & 2 & 27 & \\
\hline \multirow[t]{3}{*}{ Total } & YAG laser & 46 & 34 & 11 & 92 & 0.104 \\
\hline & Ultrasonic scalpel & 33 & 10 & 8 & 50 & \\
\hline & Total & 79 & 44 & 19 & 142 & \\
\hline
\end{tabular}

A P-value of $<0.05$ was considered significant. YAG, yttrium-aluminum-garnet.

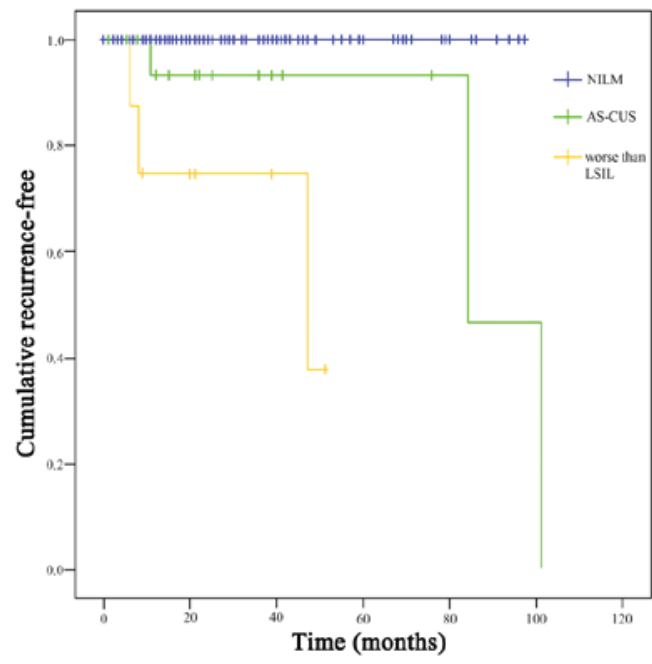

Figure 1. Cumulative recurrence-free rate. Kaplan-Meier survival curves with log-rank tests, with patient status at the time of the last follow-up visit, were used to compare the cumulative recurrence-free rates among the normal, ASC-US and worse than LSIL groups. NILM, negative for intraepithelial lesion or malignancy; ASC-US, atypical squamous cells of undetermined significance; LSIL, low-grade squamous intraepithelial lesion.

the YAG laser, and the other with a negative margin using an ultrasonic scalpel), were diagnosed with high-risk HPV. The remaining CIN 3 case (negative margin using a YAG laser and unknown, high-risk HPV status) was detected by immediate colposcopy.

On the basis of these facts, it appears reasonable to predict that women with ASC-US who have undergone treatment for CIN would be at a greater risk of developing cervical cancer compared with women with ASC-US in population-based screenings. As regards the risk stratification of women following treatment for CIN, it is crucial to determine an appropriate triage method able to identify women with ASC-US that have or will develop a cervical cancer precursor.

The risk of developing recurrent high-grade CIN (CIN 2 or CIN 3) and cervical cancer with a positive margin after treatment is high. The margin-positive recurrence rate after conization is $9-16 \%$ (13), whereas the margin-negative recurrence rate has been reported to be $2-4 \%(14,15)$. Melnikow et al noted that recurrence was defined by initial CIN grade and treatment type (5). A positive margin after treatment is one of the most important risk factors for recurrence (12), but evaluation of margins after conization may be difficult; therefore, in the present study, margin status was not assessable in some of the cases. Although there was no significant difference in recurrence of CIN 3 between the YAG laser and the ultrasonic scalpel, the use of the ultrasonic scalpel was more frequent in the abnormal group. During conization with a YAG laser, the margins are often cauterized; this may have resulted in a low incidence of abnormal cytological findings. In our hospital, a coin-shaped resection is performed for nulliparous women, often resulting in unclear or positive margins.

However, even women with clear excision margins are at risk for disease recurrence (16). The risk of developing invasive cancer after treatment for high-grade CIN is five times higher compared with that in the general population (17), which justifies closer surveillance of such patients with annual cytology and colposcopy follow-up for 10 years after treatment (18). Therefore, for women treated for CIN 3, it has been recommended that they have cytological follow-up at least 6 and 12 months after treatment, and annual cytology for the next 9 years, before resuming screening at the routine interval (19).

There was a significant difference in the time to first identification of abnormal cytology after treatment between the recurrence and the no recurrence groups (32.37 \pm 40.18 vs. 16.21 \pm 19.19 , respectively; $\mathrm{P}=0.003$; Student's t-test). However, the cumulative recurrence-free rate was a significantly better in the ASC-US group compared with that in the worse than LSIL group (log-rank test $\mathrm{P}<0.05$ ).

Cytological abnormalities during the early postoperative period are due to persistent lesions or postoperative inflammation resulting in altered cell morphology, whereas those in the late postoperative period are due to the generation of new dysplasia. According to the ACOG guidelines and a Cochrane Database systemic review (2,3), CIN recurrence was 
Table III. Course of ASC-US cases.

\begin{tabular}{|c|c|c|c|c|c|c|c|c|c|}
\hline Case & $\begin{array}{c}\text { Age } \\
\text { (years) }\end{array}$ & $\begin{array}{l}\text { Conization } \\
\text { procedure }\end{array}$ & $\begin{array}{c}\text { Margin } \\
\text { status of the } \\
\text { excised } \\
\text { specimens }\end{array}$ & $\begin{array}{l}\text { Time to first } \\
\text { identification } \\
\text { of abnormal } \\
\text { cytology after } \\
\text { treatment } \\
\text { (months) }\end{array}$ & $\begin{array}{l}\text { Management } \\
\text { after first } \\
\text { identification } \\
\text { of abnormal }\end{array}$ & $\begin{array}{l}\text { High-risk } \\
\text { HPV } \\
\text { DNA test }\end{array}$ & $\begin{array}{l}\text { Follow-up } \\
\text { after first } \\
\text { management }\end{array}$ & Final evaluation & $\begin{array}{l}\text { Follow-up } \\
\text { time } \\
\text { (months) }\end{array}$ \\
\hline 1 & 27 & $\begin{array}{l}\text { Ultrasonic } \\
\text { scalpel }\end{array}$ & Negative & 14 & $\begin{array}{l}\text { Repeat cervical } \\
\text { cytology }\end{array}$ & & $\begin{array}{l}\text { Repeat cervical } \\
\text { cytology }\end{array}$ & NILM & 35 \\
\hline 2 & 30 & $\begin{array}{l}\text { Ultrasonic } \\
\text { scalpel }\end{array}$ & Negative & 6 & $\begin{array}{l}\text { Repeat cervical } \\
\text { cytology }\end{array}$ & & $\begin{array}{l}\text { Repeat cervical } \\
\text { cytology }\end{array}$ & NILM & 22 \\
\hline 3 & 30 & $\begin{array}{l}\text { Ultrasonic } \\
\text { scalpel }\end{array}$ & Negative & 8 & $\begin{array}{l}\text { Repeat cervical } \\
\text { cytology }\end{array}$ & & $\begin{array}{l}\text { Repeat cervical } \\
\text { cytology }\end{array}$ & NILM & 18 \\
\hline 4 & 36 & $\begin{array}{l}\text { Ultrasonic } \\
\text { scalpel }\end{array}$ & Negative & 2 & $\begin{array}{l}\text { High-risk } \\
\text { HPV DNA test }\end{array}$ & Negative & $\begin{array}{l}\text { Repeat cervical } \\
\text { cytology }\end{array}$ & NILM & 22 \\
\hline 5 & 35 & $\begin{array}{l}\text { Ultrasonic } \\
\text { scalpel }\end{array}$ & Negative & 1 & $\begin{array}{l}\text { High-risk } \\
\text { HPV DNA test }\end{array}$ & Negative & Hysterectomy & No dyplasia & 11 \\
\hline 6 & 35 & $\begin{array}{l}\text { Ultrasonic } \\
\text { scalpel }\end{array}$ & Negative & 12 & $\begin{array}{l}\text { High-risk } \\
\text { HPV DNA test }\end{array}$ & Negative & $\begin{array}{l}\text { Repeat cervical } \\
\text { cytology }\end{array}$ & NILM & 22 \\
\hline 7 & 33 & $\begin{array}{l}\text { Ultrasonic } \\
\text { scalpel }\end{array}$ & Negative & 8 & $\begin{array}{l}\text { High-risk } \\
\text { HPV DNA test }\end{array}$ & Negative & $\begin{array}{l}\text { Repeat cervical } \\
\text { cytology }\end{array}$ & NILM & 18 \\
\hline 8 & 31 & $\begin{array}{l}\text { Ultrasonic } \\
\text { scalpel }\end{array}$ & Negative & 11 & $\begin{array}{l}\text { High-risk } \\
\text { HPV DNA test }\end{array}$ & Positive & $\begin{array}{l}\text { Colposcopy with } \\
\text { cervical biopsy }\end{array}$ & $\begin{array}{l}\text { CIN } 2 \\
\text { followed by } \\
\text { ASC-US }\end{array}$ & 27 \\
\hline 9 & 37 & $\begin{array}{l}\text { Ultrasonic } \\
\text { scalpel }\end{array}$ & Negative & 41 & $\begin{array}{l}\text { High-risk } \\
\text { HPV DNA test }\end{array}$ & Positive & $\begin{array}{l}\text { Colposcopy with } \\
\text { cervical biopsy }\end{array}$ & $\begin{array}{l}\text { No dysplasia } \\
\text { followed by } \\
\text { ASC-US }\end{array}$ & 51 \\
\hline 10 & 29 & YAG laser & Negative & 2 & $\begin{array}{l}\text { High-risk } \\
\text { HPV DNA test }\end{array}$ & Positive & Re-excision & $\begin{array}{l}\text { No dyplasia } \\
\text { followed by } \\
\text { NILM }\end{array}$ & 44 \\
\hline 11 & 41 & YAG laser & Negative & 84 & $\begin{array}{l}\text { Immediate } \\
\text { colposcopy }\end{array}$ & & Hysterectomy & CIN 3 & 103 \\
\hline 12 & 28 & $\begin{array}{l}\text { Ultrasonic } \\
\text { scalpel }\end{array}$ & Positive & 13 & $\begin{array}{l}\text { Repeat cervical } \\
\text { cytology }\end{array}$ & & $\begin{array}{l}\text { Repeat cervical } \\
\text { cytology }\end{array}$ & NILM & 25 \\
\hline 13 & 41 & $\begin{array}{l}\text { Ultrasonic } \\
\text { scalpel }\end{array}$ & Positive & 5 & $\begin{array}{l}\text { Repeat cervical } \\
\text { cytology }\end{array}$ & & $\begin{array}{l}\text { Repeat cervical } \\
\text { cytology }\end{array}$ & $\begin{array}{l}\text { NILM followed } \\
\text { by pregnancy }\end{array}$ & 15 \\
\hline 14 & 33 & YAG laser & Positive & 76 & $\begin{array}{l}\text { High-risk } \\
\text { HPV DNA test }\end{array}$ & Negative & $\begin{array}{l}\text { Repeat cervical } \\
\text { cytology }\end{array}$ & NILM & 86 \\
\hline 15 & 34 & YAG laser & Positive & 32 & $\begin{array}{l}\text { High-risk } \\
\text { HPV DNA test }\end{array}$ & Positive & $\begin{array}{l}\text { Colposcopy with } \\
\text { cervical biopsy }\end{array}$ & $\begin{array}{l}\text { CIN } 1 \text { followed } \\
\text { by HSIL }\end{array}$ & 49 \\
\hline 16 & 42 & YAG laser & Positive & 101 & $\begin{array}{l}\text { High-risk } \\
\text { HPV DNA test }\end{array}$ & Positive & $\begin{array}{l}\text { Colposcopy with } \\
\text { cervical biopsy }\end{array}$ & $\begin{array}{l}\text { CIN } 2 \text { followed } \\
\text { by NILM }\end{array}$ & 121 \\
\hline 17 & 35 & YAG laser & Positive & 12 & $\begin{array}{l}\text { Immediate } \\
\text { colposcopy }\end{array}$ & & $\begin{array}{l}\text { Colposcopy with } \\
\text { cervical biopsy }\end{array}$ & $\begin{array}{l}\text { No dysplasia } \\
\text { followed by } \\
\text { NILM }\end{array}$ & 32 \\
\hline 18 & 62 & YAG laser & Positive & 9 & $\begin{array}{l}\text { Immediate } \\
\text { colposcopy }\end{array}$ & & Hysterectomy & CIN 1 & 31 \\
\hline 19 & 32 & YAG laser & $\begin{array}{l}\text { Not } \\
\text { assessable }\end{array}$ & 43 & $\begin{array}{l}\text { High-risk } \\
\text { HPV DNA test }\end{array}$ & Positive & $\begin{array}{l}\text { Colposcopy with } \\
\text { cervical biopsy }\end{array}$ & $\begin{array}{l}\text { CIN } 1 \text { followed } \\
\text { by NILM }\end{array}$ & 46 \\
\hline
\end{tabular}

ASC-US, atypical squamous cells of undetermined significance; NILM, negative for intraepithelial lesion or malignancy; CIN, cervical intraepithelial neoplasia; HSIL, high-grade squamous intraepithelial lesion; HPV, human papillomavirus; YAG, yttrium-aluminum-garnet.

often observed in the first 24 months; however, in the present study, it appeared that follow-up for 48 months after surgery is necessary. Even CIN 3 recurrence was observed 5 years after surgery. Although follow-up for $>48$ months is necessary, 
Table IV. Course of worse than LSIL cases.

\begin{tabular}{|c|c|c|c|c|c|c|c|c|c|}
\hline Case & $\begin{array}{c}\text { Age } \\
\text { (years) }\end{array}$ & $\begin{array}{l}\text { Conization } \\
\text { procedure }\end{array}$ & $\begin{array}{l}\text { Margin } \\
\text { status of the } \\
\text { excised } \\
\text { specimens }\end{array}$ & $\begin{array}{c}\text { Time to first } \\
\text { identification } \\
\text { of abnormal } \\
\text { cytology after } \\
\text { treatment } \\
\text { (months) }\end{array}$ & $\begin{array}{l}\text { Cytology } \\
\text { findings }\end{array}$ & $\begin{array}{c}\text { Management } \\
\text { after first } \\
\text { identification } \\
\text { of abnormal cytology }\end{array}$ & $\begin{array}{c}\text { Follow-up } \\
\text { after first } \\
\text { management }\end{array}$ & Final evaluation & $\begin{array}{c}\text { Follow-up } \\
\text { time } \\
\text { (months) }\end{array}$ \\
\hline 1 & 34 & YAG laser & Negative & 1 & HSIL & $\begin{array}{l}\text { Colposcopy } \\
\text { with cervical } \\
\text { biopsy }\end{array}$ & $\begin{array}{l}\text { Re-excision } \\
\text { (CIN 3) }\end{array}$ & $\begin{array}{l}\text { CIN } 3 \text { followed } \\
\text { by HPV, } \\
\text { negative } \\
\text { ASC-US }\end{array}$ & 49 \\
\hline 2 & 45 & YAG laser & Negative & 4 & HSIL & Unknown & & & 4 \\
\hline 3 & 50 & YAG laser & Positive & 1 & $\mathrm{ASCH}$ & $\begin{array}{l}\text { Colposcopy } \\
\text { with cervical } \\
\text { biopsy }\end{array}$ & Hysterectomy & CIN 3 & 31 \\
\hline 4 & 26 & $\begin{array}{l}\text { Ultrasonic } \\
\text { scalpel }\end{array}$ & Positive & 47 & LSIL & $\begin{array}{l}\text { Colposcopy } \\
\text { with cervical } \\
\text { biopsy }\end{array}$ & $\begin{array}{l}\text { Re-excision } \\
\text { (CIN 3) }\end{array}$ & $\begin{array}{l}\text { CIN } 3 \text { followed } \\
\text { by NILM }\end{array}$ & 69 \\
\hline 5 & 28 & YAG laser & Positive & 12 & LSIL & Colposcopy & $\begin{array}{l}\text { Negative } \\
\text { findings } \\
\text { followed } \\
\text { by repeat } \\
\text { cytology }\end{array}$ & NILM & 61 \\
\hline 6 & 32 & YAG laser & Positive & 8 & LSIL & $\begin{array}{l}\text { Colposcopy } \\
\text { with cervical } \\
\text { biopsy }\end{array}$ & $\begin{array}{l}\text { Re-excision } \\
\text { (CIN 3) }\end{array}$ & $\begin{array}{l}\text { CIN } 3 \text { followed } \\
\text { by NILM }\end{array}$ & 44 \\
\hline 7 & 35 & YAG laser & $\begin{array}{l}\text { Not } \\
\text { assessable }\end{array}$ & 18 & LSIL & Colposcopy & $\begin{array}{l}\text { Negative } \\
\text { findings } \\
\text { followed } \\
\text { by repeat } \\
\text { cytology }\end{array}$ & NILM & 30 \\
\hline 8 & 37 & YAG laser & Positive & 6 & HSIL & $\begin{array}{l}\text { Colposcopy } \\
\text { with cervical } \\
\text { biopsy }\end{array}$ & $\begin{array}{l}\text { Re-excision } \\
\text { (CIN 3) }\end{array}$ & $\begin{array}{l}\text { CIN } 3 \text { followed } \\
\text { by NILM }\end{array}$ & 30 \\
\hline
\end{tabular}

ASC-US, atypical squamous cells of undetermined significance; NILM, negative for intraepithelial lesion or malignancy; LSIL, low-grade squamous intraepithelial lesion; HSIL, high-grade squamous intraepithelial lesion; ASC-H, atypical squamous cells, cannot exclude HSIL; CIN, cervical intraepithelial neoplasia; HPV, human papillomavirus; YAG, yttrium-aluminum-garnet.

the appropriate intervals and methods have not been fully elucidated (2).

For the first 4 years after surgery, close observation is considered necessary, but the number of patient follow-up visits decreased over time. In our hospital, $250 \%$ of cases in were followed-up for 48 months. When no cytological abnormality was identified, the follow-up was often interrupted. As only $50 \%$ of cases returned, the proportion of recurrent cases was higher. Even if the HPV test is negative, follow-up for 20 years after conization is recommended in the ACOG guidelines $(2,3)$. Continuous observation of all cases for 48 months is difficult. In order to prevent abnormal cytology or CIN 3 recurrence, margin ablation is important, particularly in coin resection cases. Margin ablation is important in the prevention of recurrence after conization, and it is possible to reduce the follow-up visits after surgery in such cases $(20,21)$.
Katki et al reported that, among ASC-US patients who tested positive for high-risk HPV, CIN 2 was diagnosed in $18 \%$, CIN 3 in $6.8 \%$, and cervical cancer in $0.41 \%$ of the cases (12). However, in patients who tested negative for high-risk HPV, CIN 2 was diagnosed in $1.1 \%$, and CIN 3 in $0.43 \%$ of the patients in previous studies $(12,22)$. High-risk HPV tests are used for risk stratification and they may be a reasonable alternative to post-treatment Pap smear cytology based on sensitivity and specificity. However, these sensitivity and specificity values are likely not applicable in a post-treatment surveillance setting, in which the prevalence of high-risk HPV is significantly higher compared with the screening phase $(5,23)$. In the post-treatment setting, it is important to distinguish between a newly detected HPV genotype or recurrent detection of a lesion-associated HPV genotype, as it has been reported that most HPV infections are cleared 12 months after surgery, whereas very few 
are cleared after this interval (24). Thus, the interpretation of the role of high-risk HPV tests for post-treatment surveillance may be difficult.

Abnormal cytology worse than LSIL suggests recurrence of CIN 3. Cytology may predict the presence and grade of dysplasia. Approximately one-fifth of patients who had abnormal postoperative cytology develop recurrence. Worse than LSIL cases are particularly likely to develop recurrence. Recurrence of CIN 3 was identified in 6 cases $(4.2 \%$ of all patients); this recurrence rate was somewhat higher compared with the reported margin-negative cases $(14,15)$. CIN 3 recurrent cases were observed within 12 months and after 42 months following conization. For early detection of recurrence, cervical smears should be performed within at least 12 months after surgery.

Although several options for post-treatment surveillance have been proposed, the current recommendations by the ACOG and the American Society of Colposcopy and Cervical Pathology suggest that, after treatment, women may require follow-up with a combination of cytology, colposcopy and the high-risk HPV test (2-4). A Cochrane Database Systematic Review found no evidence from randomized controlled trials to update decisions on the optimal surveillance strategy following treatment for CIN (2). If surveillance cytology shows ASC-US, immediate colposcopy is recommended based on the results of the present study.

Approximately one-fifth of the conization cases had CIN 3 as a postoperative cytological abnormality worse than ASC-US. Approximately one-fifth of patients with abnormal cytological findings after conization had recurrence. Worse than LSIL cases are more likely to develop recurrence. Cytological abnormalities and CIN 3 recurrence require close postoperative follow-up. As regards the risk stratification of women following treatment for CIN, if surveillance cytology shows ASC-US, immediate colposcopy is recommended, along with long-term follow-up.

\section{References}

1. Massad LS, Einstein MH, Huh WK, Katki HA, Kinney WK, Schiffman M, Solomon D, Wentzensen N and Lawson HW: 2012 ASCCP Consensus Guidelines Conference: 2012 updated consensus guidelines for the management of abnormal cervical cancer screening tests and cancer precursors. Obstet Gynecol 121: 829-846, 2013.

2. van der Heijden E, Lopes AD, Bryant A, Bekkers R and Galaal K: Follow-up strategies after treatment (large loop excision of the transformation zone (LLETZ)) for cervical intraepithelial neoplasia (CIN): Impact of human papillomavirus (HPV) test. Cochrane Database Syst Rev 1: CD010757, 2015.

3. American College of Obstetricians and Gynecologists: Practice Bulletin No. 140: Management of abnormal cervical cancer screening test results and cervical cancer precursors. Obstet Gynecol 122: 1338-1367, 2013.

4. Hanley SJ, Fujita H, Tamakoshi A, Dong P and Sakuragi N: Challenges in breast and cervical cancer control in Japan. Lancet Oncol 17: e372, 2016.

5. Melnikow J, Kulasingam S, Slee C, Helms LJ, Kuppermann M, Birch S, McGahan CE, Coldman A, Chan BK and Sawaya GF: Surveillance after treatment for cervical intraepithelial neoplasia: Outcomes, costs, and cost-effectiveness. Obstet Gynecol 116 : 1158-1170, 2010.

6. Arbyn M, Roelens J, Simoens C, Buntinx F, Paraskevaidis E, Martin-Hirsch PP and Prendiville WJ: Human papillomavirus testing versus repeat cytology for triage of minor cytological cervical lesions. Cochrane Database Syst Rev: CD008054, 2013.
7. Solomon D, Davey D, Kurman R, Moriarty A, O'Connor D, Prey M, Raab S, Sherman M, Wilbur D, WrightT Jr, et al: The 2001 Bethesda System: Terminology for reporting results of cervical cytology. JAMA 287: 2114-2119, 2002.

8. Cox JT, Castle PE, Behrens CM, Sharma A, Wright TC Jr and Cuzick J; Athena HPV Study Group: Comparison of cervical cancer screening strategies incorporating different combinations of cytology, HPV testing, and genotyping for HPV 16/18: Results from the ATHENA HPV study. Am J Obstet Gynecol 208: 184.e1-184.e11, 2013.

9. Mayrand MH, Duarte-Franco E, Rodrigues I, Walter SD, Hanley J, Ferenczy A, Ratnam S, Coutlée F and Franco EL; Canadian Cervical Cancer Screening Trial Study Group: Human papillomavirus DNA versus Papanicolaou screening tests for cervical cancer. N Engl J Med 357: 1579-1588, 2007.

10. López-Alegría F, Poblete OQ, De Lorenzi DS and Oyanedel JC: Clinical management of the first ASCUS report in Chile. Prospective single-cohort study. Sao Paulo Med J 133: 480-487, 2015.

11. Solomon D, Schiffman M and Tarone R; ALTS Study group: Comparison of three management strategies for patients with atypical squamous cells of undetermined significance: Baseline results from a randomized trial. J Natl Cancer Inst 93: 293-299, 2001.

12. Katki HA, Schiffman M, Castle PE, Fetterman B, Poitras NE, Lorey T, Cheung LC, Raine-Bennett T, Gage JC and Kinney WK: Five-year risk of recurrence after treatment of CIN 2, CIN 3, or AIS: Performance of HPV and Pap cotesting in posttreatment management. J Low Genit Tract Dis 17 (5 Suppl 1): S78-S84, 2013.

13. Morris M, Mitchell MF, Silva EG, Copeland LJ and Gershenson DM: Cervical conization as definitive therapy for early invasive squamous carcinoma of the cervix. Gynecol Oncol 51: 193-196, 1993.

14. Vedel P, Jakobsen H, Kryger-Baggesen N, Rank F and Bostofte E: Five-year follow up of patients with cervical intra-epithelial neoplasia in the cone margins after conization. Eur J Obstet Gynecol Reprod Biol 50: 71-76, 1993.

15. White CD, Cooper WL and Williams RR: Cervical intraepithelial neoplasia extending to the margins of resection in conization of the cervix. J Reprod Med 36: 635-638, 1991.

16. Paraskevaidis E, Kalantaridou SN, Kaponis A, Chouliara S, Agnantis NJ, Dousias V, Zikopoulos K, Paschopoulos M, Stamatopoulos P and Lolis DE: Surgical management of early stage cervical cancer: Ten years experience from one Greek health region. Eur J Gynaecol Oncol 23: 341-344, 2002.

17. Brown JV, Peters WA and Corwin DJ: Invasive carcinoma after cone biopsy for cervical intraepithelial neoplasia. Gynecol Oncol 40: 25-28, 1991

18. Jeong NH, Lee NW, Kim HJ, Kim T and Lee KW: High-risk human papillomavirus testing for monitoring patients treated for high-grade cervical intraepithelial neoplasia. J Obstet Gynaecol Res 35: 706-711, 2009.

19. Leguevaque P, Motton S, Decharme A, Soulé-Tholy M, Escourrou G and Hoff J: Predictors of recurrence in high-grade cervical lesions and a plan of management. Eur J Surg Oncol 36: 1073-1079, 2010

20. Bar-Am A, Daniel Y, Ron IG, Niv J, Kupferminc MJ, Bornstein J and Lessing JB: Combined colposcopy, loop conization, and laser vaporization reduces recurrent abnormal cytology and residual disease in cervical dysplasia. Gynecol Oncol 78: 47-51, 2000.

21. Duesing N, Schwarz J, Choschzick M, Jaenicke F, Gieseking F, Issa R, Mahner S and Woelber L: Assessment of cervical intraepithelial neoplasia (CIN) with colposcopic biopsy and efficacy of loop electrosurgical excision procedure (LEEP). Arch Gynecol Obstet 286: 1549-1554, 2012.

22. Nishimura M, Miyatake T, Nakashima A, Miyoshi A, Mimura M, Nagamatsu M, Ogita K and Yokoi T: Clinical significance of atypical squamous cells of undetermined significance among patients undergoing cervical conization. Asian Pac J Cancer Prev 16: 8145-8147, 2015.

23. Chan BK, Melnikow J, Slee CA, Arellanes R and Sawaya GF: Posttreatment human papillomavirus testing for recurrent cervical intraepithelial neoplasia: A systematic review. Am J Obstet Gynecol 200: 422. e1-e9, 2009.

24. Pirtea L, Grigoraş D, Matusz P, Pirtea M, Moleriu L, Tudor A, Ilina R, Secoşan C, Horhat F and Mazilu O: Human papilloma virus persistence after cone excision in women with cervical high grade squamous intraepithelial lesion: A prospective study. Can J Infect Dis Med Microbiol 2016: 3076380, 2016. 